\title{
Asiantuntemusta tulisi lisätä eikä vähentää
}

Kritikoin lehden viime numerossa Aikuiskoulutusneuvoston kokoonpanoa. Kokoonpanoon eivät näytä olevan muutkaan tyytyväisiä, vaikkakin kritiikin kohteet ovat aivan toiset kuin mitä minä esitin. Vapaan sivistystyön yhteisjärjestö ja Kansalais- ja työväenopistojen liiton valtuusto ovat lähettäneet opetusministeriölle suurin piirtein samansisältöisen kannanoton, jossa arvostellaan aikuiskoulutusneuvoston kokoonpanoa. Molemmissa lausunnoissa todetaan, että vapaa sivistystyö ei ole riittävästi edustettuna neuvostossa ja että kansalais- ja työväenopistojen edustus puuttuu kokonaan. Vapaan sivistystyön yhteisjärjestön lausunnossa todetaan myös, että neuvoston kokoonpanossa ei ole otettu riittävästi huomioon parlamentaarisia voimasuhteita. Saman asian toteavat oman puolueensa osalta myös joukko Kokoomuspuolueen kansanedustajia, jotka tekivät valtioneuvostolle asiaa koskevan kirjallisen kyselyn.

Opetusministeri Suonio vastasi kyselyyn huhtikuun lopulla ja torjui vastauksessaan esitetyt syytökset. Hänen mukaansa neuvoston kolmestatoista varsinaisesta jäsenestä on viisi vapaan sivistystyön järjestöjen työntekijöitä tai vastuunalaisissa luottamustehtävissä näissä järjestöissä. Kansalais- ja työväenopistojen edustus neuvostossa on tarkoitus hoitaa sihteerivalintojen kautta. Poliittisen diskriminaation opetusministeri Suonio myös kiistää, kuten hänen tässä lehdessä toisaalla olevasta vastauksestaan ilmenee. Lopuksi hän toteaa, ettei hallitus aio ryhtyä neuvoston jäsenten ja varajäsenten kokoonpanon muuttamiseen alkaneen kolmivuotiskauden aikana. Asia on siis poissa päiväjärjestyksestä - vai onko? Eikö aikuiskoulutusneuvostolle pitäisi antaa nyt työrauha ja katsoa sitten kauden loputtua, mitä on saatu aikaan?

Näin tietysti päätöksentekijät toivovat. Mielestäni heillä ei ole kuitenkaan mitään syytä itsetyytyväisyyteen. Tosiasiaksi nimittäin jää, että vapaan sivistystyön asiantuntemus on entisestään vähentynyt valtionhallinnossa. Sillä ei ole enää siellä mitään omaa asiantuntijaelintä, kuten oli vielä Valtion kansansivistyslautakunnan toimiessa. Jos kansansivistyslautakunta ei toiminut tyydyttävästi, niin miksei sitä kehitetty nykyhetken tarpeita vastaavaksi alan asiantuntijaelimeksi. Edistyksenä ei voida pitää sitä, että meillä on nyt yksi yleinen asiantuntijaelin, jonka toimintaan - näin luulisin - eivät tule olemaan tyytyväisiä sen paremmin vapaan sivistystyön kuin aikuisten ammatillisen koulutuksenkaan edustajat. Järkevämpää olisi ollut kehittää entistä kansansivistyslautakuntaa ja perustaa työelämän ammatillista koulutusta varten oma asiantuntijaelin ammattikasvatushallituksen yhteyteen. Yhtenä vaihtoehtona olisi ollut erityisen aikuisten ammatillisen perus- ja lisäkoulutuksen jaoston perustaminen Ammattikasvatusneuvostoon. 
Vapaa sivistystyö ja työelämän koulutus muodostavat kumpikin nykyisin niin laajan ja eriytyneen kokonaisuuden, että niitä varten tarvitaan ehdottomasti omat asiantuntijaelimet. Näiden molempien alueiden ongelmien perinpohjainen käsittely yhden yleisen asiantuntijaelimen piirissä on vaikeaa, koska toiminnan lähtökohdat ja tavoitteet ovat niin erilaisia. Vapaan sivistystyön tehtävänä on tukea aikuisia heidän itsekasvatuspyrkimyksissään ja tarjota heille siihen käytännössä mahdollisuudet. Työelämän koulutuksessa on sen sijaan kysymys yhteiskunnan ja sen eri organisaatioiden koulutustarpeiden tyydyttämisestä. On selvää, etteivät nämä erilaiset lähtökohdat ja tavoitteet ole täysin toisilleen vastakkaisia, mutta eri näkökulmista johtuen toiminnot saavat käytännössä aivan erilaisen luonteen. Molempia aikuiskasvatuksen sektoreita tulee edelleen kehittää, kuten periaatepäätöksessäkin todetaan. Vaikka kehittämistyön pääpaino onkin ammatillisessa koulutuksessa, ei se saa tapahtua vapaan sivistystyön resursseja vähentämällä.

Näyttää siltä, että vapaa sivistystyö ei ole pystynyt taistelemaan itselleen sitä asemaa, joka sille aikuiskasvatuksen vanhimpana ja hallinnollisesti kehittyneimpänä alueena kuuluisi. Ainakin osittain vapaan sivistystyön organisaatiot saavat syyttää tästä itseään. Kutakin organisaatiota näyttää kiinnostaneen enemmän omien intressien ajaminen, jolloin yhteiset peruslähtökohdat ja-tavoitteet ovat jääneet taka-alalle. Näin ei valtionhallinnon byrokraateille näytä muodostuneen selvää käsitystä tämän sektorin kokonaismerkityksestä ja erityisluonteesta.

Koko kehittämistoiminnan ajan ovat vapaan sivistystyön edustajat olleet huolestuneita oman alansa tulevaisuudesta, eivätkä varmaankaan syyttä. Sen sijaan ammatillisen sektorin puolelta ei ole esitetty kehittämistoimintaa kohtaan mitään kritiikkiä. Tätä voitaneen pitää merkkinä siitä, että kehittämissuunnitelmat vastaavat paremmin heidän tarpeitaan. Tästä epätasapainoisesta tilanteesta pitäisi päästä vähitellen eroon. Ratkaisuna voisi olla esim. edellä hahmottelemani kaksitahoinen kehittämisstrategia, jossa molempia aikuiskasvatuksen pääsektoreita kehitettäisiin omien asiantuntijaorganisaatioiden toimesta ja ottaen huomioon näiden alueiden omat erityiset lähtökohdat ja tavoitteet. En usko, että tässä onnistutaan kovin hyvin nykyisin Aikuiskoulutusneuvoston toimesta. Aika sen näyttää. Palataanko asiaan vasta kolmen vuoden kuluttua arvoisat päätöksentekijät? 